\title{
A Survey on Effect of Agro Waste Ash as Reinforcement on Aluminium Base Metal Matrix Composites
}

\author{
Prasanna P. Kulkarni' ${ }^{1}$, B. Siddeswarappa², Kariyappla Shivashankar Hemanth Kumar' \\ ${ }^{1}$ Department of Mechanical Engineering, STJ Institute of Technology, Ranibennur, India \\ ${ }^{2}$ Department of Studies in Industrial Production Engineering, University BDT College of Engineering, Davanagere, India \\ Email: Prasanna.pk05@gmail.com, Siddeswarappa1956@gmail.com, hemanth.2516@gmail.com
}

How to cite this paper: Kulkarni, P.P., Siddeswarappa, B. and Hemanth Kumar, K.S. (2019) A Survey on Effect of Agro Waste Ash as Reinforcement on Aluminium Base Metal Matrix Composites. Open Journal of Composite Materials, 9, 312-326. https://doi.org/10.4236/ojcm.2019.93019

Received: December 19, 2018

Accepted: July 28, 2019

Published: July 31, 2019

Copyright () 2019 by author(s) and Scientific Research Publishing Inc. This work is licensed under the Creative Commons Attribution International License (CC BY 4.0).

http://creativecommons.org/licenses/by/4.0/

\begin{abstract}
In the present day availability of agricultural waste products is very huge quantity. Most of the industries prefer Metal matrix composite (MMC) due to their density, high strength to weight ratio, hardness, corrosion resistance, fatigue and creep resistance. Hence they are widely used in structural applications along with aerospace and automobile industry, marine, sports, electronic and automation industries. In the present paper a study is focused on the mechanical, tribological and corrosion behavior of the metal matrix composite using different agro waste ash which is easily available. Agro waste ash like Rice Husk, groundnut shell, bamboo leaf, coconut shell can be used as reinforcement and applicable for various applications like automotive, structural components. From this current study, it's clearly identified that addition of agro waste ash as reinforcement with Aluminium improves the properties of metal matrix composite. Aluminium metal with such reinforcement materials has shown a high specific strength, yield strength and ultimate tensile strength, also it will increase hardness, satisfactory levels of corrosion resistance.
\end{abstract}

\section{Keywords}

Metal Matrix Composite, Agro Waste Ash Reinforcement, Mechanical Behavior, Tribological Behavior, Corrosion Properties

\section{Introduction}

Aluminum is widely used as a structural material especially in the aerospace industry because of its light weight property. However, the low strength and low 
melting point were always a problem. A cheap method of solving these problems was the use of reinforcement element such as $\mathrm{SiO}_{2}, \mathrm{SiC}$ particles and whiskers or other elements or compounds as alloying element.

Metal matrix composites (MMCs) like Al600 series (Al6061/6063) are of great interest in industrial applications for lighter materials with high specific strength, stiffness and heat resistance. The processing of MMCs by casting process is a very promising way of manufacturing near net shape composites at a relatively low cost. The 6000 series of aluminum alloys have so far exhibited remarkable mechanical properties, formability, higher corrosion resistance, better weld ability, high strength-to-weight ratio and a lower cost as compared to other counterparts, such as the 2000 and the $7000 \mathrm{Al}$ alloys. This set of aluminum alloys constitutes the highest volume of aluminum products, which have been widely employed in a variety of technologies, including automobile and aerospace industries, pipes, architectural applications, bicycle frames, transportation equipment, bridge railings and welded structures. Among the vast variety of alloying elements available for the development of the heat-treatable 6000 series, recent investigations have proposed silicon and magnesium as the major alloying elements. Moreover, both elements are essential materials for precipitate strengthening [1] [2] [3] [4]. Furthermore, aluminum AA6063 alloy is widely employed for construction and transportation applications [5].

Research efforts have been geared towards the use of recycled wastes as reinforcing fillers to develop composite. Today's world has been looking for the maximum optimization as possible in every field and "engineering" is not an exception. In the quest for these developments, much affected is the environment. So the development of low cost metal matrix composites reinforced with eco-friendly material has been one of the major innovations in the field of materials to curtail environmental pollution.

The different reinforcing materials used in the development of AMCs can be classified into three broad groups:

Synthetic ceramic particulates

Industrial wastes

Agro waste derivatives.

Parameters considered for design of AMCs are linked with reinforcing materials. A few of such parameters are reinforcement type, size, and shape, and volume fraction, modulus of elasticity, hardness \& manufacturing process.

\section{Synthetic Ceramic Particulates}

Silicon carbide $(\mathrm{SiC})$, alumina $\left(\mathrm{Al}_{2} \mathrm{O}_{3}\right)$, boron carbide $(\mathrm{B} 4 \mathrm{C})$, tungsten carbide (WC), graphite $(\mathrm{Gr})$, carbon nanotubes $(\mathrm{CNT})$ and silica $\left(\mathrm{SiO}_{2}\right)$ are some of the synthetic ceramic particulate that has been studied but silicon carbide and alumina are mostly utilized compared to other synthetic reinforcing particulates [6]. Conventional AMCs reinforced with $\mathrm{SiC}$ or $\mathrm{Al}_{2} \mathrm{O}_{3}$ have shown improved strength and specific stiffness over the monolithic alloys but this occurs at the expense of ductility and fracture toughness [7] [8] and [9]. 
Reinforcement is usually composed of non-metal components and generally conventional ceramic materials, such as $\mathrm{SiC}, \mathrm{Al}_{2} \mathrm{O}_{3}$, and flyash and so on. Many important automotive components, such as pistons, cylinders, engine blocks, brakes, drive shafts and snow tire studs, have used aluminum matrix composites in their production. The new aluminum matrix composite engine has provided a higher compactness with great weight reductions compared with traditional engine blocks and those fabricated in aluminum alloys with other metal alloy liners, which thus provides a higher level of performance [5].

Reinforcement Fly Ash (FA) and Red Mud are typical industrial waste gotten from the power plant and aluminium industry respectively [10] [11]. These wastes have been suggested to be suitable for use as reinforcing materials in AMCs. Although research work reporting the use of red mud as reinforcement in MMCs are sparse, extensive studies have been carried out on the use of fly ash as reinforcement in both single and hybrid composites.

Among the various MMCs, aluminium based alloys are widely utilized in the production of MMCs and have reached the industrial production stage due to their aforementioned superior properties [12] [13] [14] [15] [16].

During the last three decades, $\mathrm{TiC}, \mathrm{AlN}, \mathrm{B}_{4} \mathrm{C}, \mathrm{Al}_{2} \mathrm{O}_{3}, \mathrm{TiB}_{2}, \mathrm{MoS}_{2}, \mathrm{SiC}, \mathrm{Gr}$ and mica, have widely used as the reinforcement particles at various mesh sizes in the aluminium matrix which improved the hardness, tensile strength, elastic modulus and wear resistance [17]-[24].

The use of inexpensive reinforcements such as natural material might reduce the overall cost of AMMCs and may also increase its functionality in different applications [25]. The search for low cost options in AMMC production has led to a number of efforts tailored at utilizing industrial and agro waste products as reinforcing materials. Similarly it was observed by author Marin E. et al. [26] that the cost of aluminium metal matrix composite (AMMCs) remains high, which limits its applications. The use of inexpensive reinforcements such as natural material might reduce the overall cost of AMMCs and may also increase its functionality in different applications.

In this regard, a number of researchers made attempts on agro waste ashes such as baggase ash, rice husk ash (RHA), coconut shell ash, palm kernel shell ash, groundnut shell ash (GSA) and bamboo leaf ash as complementing reinforcements. The agro waste ash contains a high content of silicon dioxide $\left(\mathrm{SiO}_{2}\right)$ with the distribution of other elements such as $\mathrm{Al}_{2} \mathrm{O}_{3}, \mathrm{Fe}_{2} \mathrm{O}_{3}, \mathrm{CaO}, \mathrm{MgO}$ and $\mathrm{C}$ [27]-[32].

However, Metal matrix composite technology is still in developing stage and several important combinations of reinforcement especially agro-based ash are yet to study. In this regards many researchers are made attempt on agro waste ash as reinforcement material with metal matrix composites as given below.

\section{Literature Review}

Study was carried out by C.U. Atuanya et al. [33] that Fabricated Al-Si-Fe alloy 
matrix composites reinforced with breadfruit seed hull ash particles of size 500 $\mathrm{nm}$ by varying weight fractions through double stir casting method. Microstructural study revealed that with increase in weight fraction of reinforcement, the matrix grain size decreases. The mechanical properties were improved with increase in weight percentage. Fracture study showed that fracture initiation does not occur at the particle-matrix interface.

Prepared Al 1100 metal matrix composites reinforced with 15\% coconut shell ash of size $60 \mu \mathrm{m}$ through compo casting carried out by Ankesh Kumar et al. [34]. It was found that the density of Al-CSAp composite is less than $\mathrm{Al}$ alloy. The average density of composite was 0.3628 gms. The Al-CSAp composite exhibit harder than $\mathrm{Al}$ material due to the presence of hardening substances like $\mathrm{SiO}_{2}$ and $\mathrm{MgO}$ in the reinforced material.

S. B. Hassan et al. [35] found that, a fabricated $\mathrm{Al}-\mathrm{Cu}-\mathrm{Mg}$ composites reinforced with egg shell particles of $2-12 \mathrm{wt} \%$ The results revealed that the tensile strength increased by $8.16 \%$ at $12 \mathrm{wt} \%$ uncarbonized ES and $14.28 \%$ at $12 \mathrm{wt} \%$ carbonized ES, the hardness values increased by $10.01 \%$ at $12 \mathrm{wt} \%$ uncarbonized ES and $25.4 \%$ at $12 \mathrm{wt} \%$ carbonized ES with decrease in the density by $6.50 \%$ at $12 \mathrm{wt} \%$ uncarbonized ES and $7.4 \%$ at $12 \mathrm{wt} \%$ carbonized ES. The impact energy decreased by $23.5 \%$ at $12 \mathrm{wt} \%$ uncarbonized ES and $24.67 \%$ at $12 \mathrm{wt} \%$ carbonized ES particles, respectively.

Prepared AlSi10Mg composites reinforced with rice husk ash of different particle sizes like $50-75,75-100$ and $100-150 \mu \mathrm{m}$ by $3 \%, 6 \%, 9 \%$, and $12 \%$ by weight through the liquid metallurgy method studied by S. D. Saravanan [36] The results revealed that composite reinforced with coarse rice husk particles shows better wear resistance compared to fine particles. The wear rate of composite decreased with increase in the weight percentage of rice husk.

T. B. Asafa et al. [37] investigated that, Fabricated Aluminum metal matrix composites reinforced with snailshell particles of weight fraction ranging from 16 to $48 \mathrm{wt} \%$ and size of 200, 400 and $600 \mu \mathrm{m}$ by using stir casting technique The results showed that, at $48 \mathrm{wt} \%$ and $600 \mu \mathrm{m}$ particle size the tensile strength was $236 \mathrm{MPa}$ and hardness was $48.3 \mathrm{HRF}$, respectively.

Manufactured Aluminum 6063 alloy composites reinforced with $150 \mu \mathrm{m}$ walnut powder by wt $\%$ of $3 \%, 5 \%$, and $7 \%$ through stir casting which is carried out by Omole et al. [38] and revealed that At 7\% of reinforcement the hardness is high with value of $113.6 \mathrm{BHN}$ and tensile properties were also increased compared to other composites.

Kenneth Kanayo ALANEME et al. [39] found that, the corrosion behavior of Al-Mg-Si alloy based composites reinforced with groundnut shell ash (GSA) and silicon carbide $(\mathrm{SiC})$ was investigated. The aim is to assess the corrosion properties of Al-Mg-Si alloy based hybrid reinforced composites developed using different mix ratios of GSA (a cheaply processed agro waste derivative which served as partial replacement for $\mathrm{SiC}$ ) and $\mathrm{SiC}$ as reinforcing materials. GSA and $\mathrm{SiC}$ mixed in weight ratios $0: 1,1: 3,1: 1,3: 1$, and 1:0 were utilized to prepare 6 and 10 $\mathrm{wt} \%$ of the reinforcing phase with Al-Mg-Si alloy as matrix using two-step stir 
casting method.

The results show that the Al-Mg-Si alloy based composites containing 6 and $10 \mathrm{wt} \% \mathrm{GSA}$ and $\mathrm{SiC}$ in varied weight ratios were resistant to corrosion in 3.5\% $\mathrm{NaCl}$ solution. The composites were however more susceptible to corrosion in $0.3 \mathrm{M} \mathrm{H}_{2} \mathrm{SO}_{4}$ solution (in comparison with the $3.5 \% \mathrm{NaCl}$ solution). It was noted that the $\mathrm{Al}-\mathrm{Mg}-\mathrm{Si} / 6 \mathrm{wt} \% \mathrm{GSA}-\mathrm{SiC}$ hybrid composite grades containing GSA and $\mathrm{SiC}$ in weight ratio 1:3 and 3:1 respectively exhibited superior corrosion resistance in the $0.3 \mathrm{M} \mathrm{H}_{2} \mathrm{SO}_{4}$ solution compared to other composites produced for this series. In the case of the Al-Mg-Si/10 wt\% GSA-SiC hybrid composite grades, the corrosion resistance was relatively superior for the composites containing a greater weight ratio of GSA (75\% and $100 \%)$ in $0.3 \mathrm{M} \mathrm{H}_{2} \mathrm{SO}_{4}$ solution.

In the work of K. K. Alaneme et al. [40] investigated that, the ash produced during the incineration of bamboo leaf was used as a reinforcing phase incorporating with $\mathrm{Al}_{2} \mathrm{O}_{3}$ (Alanemeand Adewuyi, 2013). The main component of bamboo leaf ash are $\mathrm{SiO}_{2}$ (76.4 wt\%), $\mathrm{Al}_{2} \mathrm{O}_{3}$ (5.04 wt\%), $\mathrm{MgO}$ (2.05 wt\%), $\mathrm{K}_{2} \mathrm{O}$ (5.76 wt\%), $\mathrm{CaO}(6.68 \mathrm{wt} \%)$ and $\mathrm{Fe}_{2} \mathrm{O}_{3}$, which are stable Phases or can be converted to other stable and desirable phases during fabrication rout. Bamboo leaf ash with $\mathrm{Al}_{2} \mathrm{O}_{3}$ powders with the ratio of $0: 10,2: 8,3: 7$, and $4: 6 \mathrm{wt} \%$ were introduced to molten alloy through double stir casting method. It was reported that, although increasing the weight percentage of bamboo leaf ash leads to decrement of hardness and tensile strength, this decrease is insignificant. On the other hand, the fracture toughness of all hybrid composite compositions $\left(\mathrm{Al} / \mathrm{BLA} / \mathrm{Al}_{2} \mathrm{O}_{3}\right)$ was superior to that of the single reinforced composite. Bamboo leaf ash is cheaper than alumina, thus part of alumina in the $\mathrm{Al} / \mathrm{Al}_{2} \mathrm{O}_{3}$ composites can be replaced with bamboo leaf ash.

W. A. Ajibola et al. [41] observed that the microstructure and mechanical characteristic of Zinc-Aluminum composite reinforced with coconut shell ash (CSA) and silicon carbide was examined. Five samples were prepared with compositions 0 wt $\%$ SiC particles added with $0,1,2,3,4$, and 5 wt $\%$ CSA were utilized to prepare $10 \mathrm{wt} \%$ of the reinforcing phase with Zinc-Aluminum matrix composite using two-step stir casting method. The agro waste material was preheated to a temperature of $250^{\circ} \mathrm{C}$ before being introduced into the Zinc-Aluminum composite in molten state. Mechanical properties were used to characterize the composites produced. The result shows that decrease in the percentage of $\mathrm{SiC}$ resulted to a corresponding decrease in hardness and wear resistance while increase in CSA led to increase in shear strength and torsion. The microstructure shows that $\mathrm{SiC}$ and CSA were well dispersed in the alloy matrix. In conclusion, the hardness and wear characteristics of the composite improved with increased in $\mathrm{SiC}$ reinforcement.

Recently Atuanya et al. [42] investigated the effect of breadfruit seed hull ash on the microstructures and properties of Al-Si-Fe alloy/breadfruit seed hull ash particulate composites fabricated through stir casting technique. It was found that the density of the breadfruit seed hull ash is $1.98 \mathrm{~g} / \mathrm{cm}^{3}$ which means that breadfruit seed hull ash is very light material. The value obtained fall within the 
range of density of fly ash and bagasse ash which are 1.8 and $2.2 \mathrm{~g} / \mathrm{cm}^{3}$.

Prasad et al. [43] carried out an investigation on stir cast aluminium hybrid composite containing equal amount of rice husk ash and silicon carbide from $2 \%$ to $8 \%$ in step of 2 . They found out that there was homogenous distribution of the reinforcement in the matrix. Hardness, yield strength and ultimate tensile strength increased with increase in the reinforcement while percentage elongation and CTE had inverse relationship with increasing reinforcement.

Alaneme et al. [44] studied the influence of BLA (Bamboo leaf ash) on the corrosion performance of hybrid AMCs reinforced with BLA and SiC using gravimetric analysis. They revealed that the BLA improved corrosion resistance in $3.5 \% \mathrm{NaCl}$ while the single reinforced $\mathrm{Al}-\mathrm{Mg}-\mathrm{Si} / 10 \mathrm{wt} \% \mathrm{SiC}$ had superior corrosion resistance in $0.3 \mathrm{M} \mathrm{H}_{2} \mathrm{SO}_{4}$. Similar observation of inferior corrosion resistance due to RHA was also reported for hybrid $\mathrm{Al}-\mathrm{Mg}$-Si/SiC RHA composites in $3.5 \mathrm{wt} \% \mathrm{NaCl}$ environment Although RHA and BLA can effectively avoid the formation of $\mathrm{Al}_{4} \mathrm{C}_{3}$ phase during the fabrication of hybrid AMCs, the precipitation of $\mathrm{Mg}_{2} \mathrm{Si}$ in some cases enhance localized corrosion. In general, for most of the hybrid AMCs, the wear rates are comparable with the single reinforced AMCs. The wear performances of certain mix ratios of the reinforcements (agro waste derivatives + synthetic ceramic materials) are usually superior to that of the single reinforced AMCs.

Adnan Adib Ahamed, et al. [45] has article highlights on the work where an attempt is taken to fabricate aluminium matrix composite reinforced with rice husk ash (RHA) particles, an agricultural byproduct with high amount of silica. RHA particles, upon analysis, are incorporated into the $\mathrm{Al}$ matrix melt by stir casting. Magnesium $(\sim 1 \%)$ is used as a wetting agent between matrix and reinforcement. 3\%, 6\% and 9\% wt. of RHA are added into the matrix. The microstructure analysis reveals the reinforcing particle distribution inside the matrix which indicates successful fabrication of the composites. The density and mechanical properties such as strength and hardness are measured for both unreinforced metal and composites. The results found in the tests show a decrease in density with increasing reinforcement while increasing yield strength, ultimate strength and hardness of the composites with increasing reinforcement from the unreinforced condition.

B. Praveen KUMAR et al. [46], the fabricated composite specimens were subjected to various tests to determine the mechanical properties such as density, porosity, hardness and tensile strength. The results were compared with basic matrix alloy. Furthermore, the OM, SEM with EDAX and XRD analyses were carried out to analyze the dispersion of the reinforced particles in the selected matrix alloy. It was observed that the homogeneous distribution of BLA particles in composites was intragranular in nature. Moreover, it was also observed that BLA particles were well bonded with matrix alloy with clear interface. It was also found that the density decreased with increase in mass fraction of BLA particles and porosity increased with increase in mass fraction of BLA particles. The hardness and tensile strength were increased up to $4 \%$ of BLA in the composite, 
with a further increase in BLA content the hardness and tensile strength decreased.

Recently, work carried out on a characterization of coconut shell ash for potential utilization in metal matrix composites was studied by P. B Madakson et al. [47]. The result showed that coconut shell ash contains Silicon Oxide $\left(\mathrm{SiO}_{2}\right)$, Cordierite $\left(\mathrm{Mg}_{2} \mathrm{AlSi}_{5} \mathrm{O}_{18}\right)$, Quartz $\left(\mathrm{SiO}_{2}\right)$ and Moissanite $(\mathrm{SiC})$ as the primary compound with $\mathrm{SiO}_{2}$ as the highest percentage of all the compound and element present. In addition, XRF studies revealed the presence of hard phases like $\mathrm{SiO}_{2}$, $\mathrm{Al}_{2} \mathrm{O}_{3}, \mathrm{MgO}$ and $\mathrm{Fe}_{2} \mathrm{O}_{3}$ as major constituents. The coconut shell ash can withstand a temperature of up to $1500^{\circ} \mathrm{C}$ with a density of $2.05 \mathrm{~g} / \mathrm{cm}^{3}$. According to the results and in comparison with other waste material applied as reinforcement in MMCs, the authors have suggested coconut shell ash as a light and hard component for fabricating of MMCs.

Aigbodion et al. [48] studied that the effect of bagasse ash reinforcement on the wear behavior of $\mathrm{Al}-\mathrm{Cu}-\mathrm{Mg} /$ Bagasse ash particulate composites. The tests were conducted at varying loads, from 5 to $20 \mathrm{~N}$ and different sliding speeds for a constant sliding distance of $5000 \mathrm{~m}$. The result showed that the aluminum alloy reinforced with Bagasse ash particles exhibits better dry sliding wear resistance than the unreinforced alloy. Wear rate decreases as the amount of bagasse ash particles reinforcement increased in the alloy. In addition, the microstructure of the worn surface revealed that a large amount of plastic deformation occurred on the surface of the unreinforced aluminum alloy. While $\mathrm{Al}-\mathrm{Cu}-\mathrm{Mg} / \mathrm{BAp}$ reinforced alloy, the worn out surfaces are not smooth, and grooves, scratches and parallel lines were observed. By increasing the sliding speed and the applied load, the wear rate increased.

In the work by Deshmukh et al. [49] the mechanical properties of $\mathrm{Al}$ based MMC reinforced with RHA and metallurgical grade $\mathrm{SiO}_{2}$ with varying percentage of $\mathrm{Mg}(0.5,1,2.5$ and $5 \mathrm{wt} \%)$ was studied. To fabricate the composites, amorphous $\mathrm{SiO}_{2}$ (extracted from rice husk) was added in proportion of $5 \mathrm{wt} \%$, into the alloy samples by the stir casting route, repeating the procedure for the metallurgical grade $\mathrm{SiO}_{2}$. The $\mathrm{SiO}_{2}$ extracted from rice husk was in the range of $32-56 \mathrm{~nm}$ while the metallurgical grade $\mathrm{SiO}_{2}$ was about $10 \mu \mathrm{m}$ average size. It was reported that with the increasing of $\mathrm{Mg}$ percent up to $2.5 \mathrm{wt} \%$ to the molten alloy, the hardness values increased in both fabricated composites. This can be attributed to a better wet ability of $\mathrm{SiO}_{2}$ particles and formation of hard phase of spinel and a solid solution of $\mathrm{Mg}$ in $\mathrm{Al}$ matrix in the presence of $2.5 \mathrm{wt} \% \mathrm{Mg}$. Consequently, excessive lattice distortion of $\mathrm{Al}$ occurs, resulting in the formation of finer grains with higher hardness. Besides, Nano scale $\mathrm{SiO}_{2}$ derived from rice husk has more reactivity and surface area with molten alloy than metallurgical grade $\mathrm{SiO}_{2}$ and hence, the former results in the formation of porosity and the later causes less contact area with the matrix. The wear loss of $\mathrm{Al}-2.5 \mathrm{wt} \% \mathrm{Mg}$ composite reinforced with rice husk silica was also found to be minimum than that of other samples of composites. From the SEM micrographs of the worn out particles it was concluded that for the composite with $2.5 \% \mathrm{Mg}$ and with rice 
husk silica as reinforcement, the minimum worn out particles are seen which is equivalent to maximum hardness and minimum wear loss.

L. Lancaster et al. [50] published a detailed study of the utilization of agro-based materials like coconut shell ash, rice husk etc. as reinforcement materials. The wear, corrosion, mechanical and physical properties of the MMC was studied along with the future potential and application of agro-based waste product as reinforcement material in composites in various industrial sectors like automobile, aerospace and other sectors. It was concluded that addition of agro-based products like coconut shell ash enhanced the existing material. Further, it was concluded that these agro-based products can be used as a material of reinforcement in producing better composites to be further used in automobile, industry, construction industry and various other industries.

Ajit Kumar Senapati et al. [51] has reviewed that the utilization of waste products as reinforcement in MMCs. There again it was concluded that the addition of waste product like coconut shell ash as reinforcement, the properties of the existing material got enhanced and improved in different properties of composite materials.

It was observed by Ankesh Kumar et al. [52] that the Hybrid MMCs are the advanced engineering materials in which there are a reinforcement of two or more different materials which leads to the enhancement of physical, mechanical and machinability properties. In this view, the present analysis focuses on the study of Al-Coconut shell ash metal matrix composites. The present paper is aimed to review the enhancement in mechanical combined with physical properties and machinability characteristics of aluminium in the presence of reinforcement with Coconut shell ash (CSA). Density and hardness will be tested and in the later part analysis of machinability properties for composite. The machinability characteristics are designed by taguchi orthogonal array [L9] to determine the influence process parameters. Speed, feed rate and depth of cut are process parameters with responses are surface roughness for aluminium alloy and composite with $15 \%$ of CSA. Analysis of variance (ANOVA) revels the best optimal condition and influence of parameters on surface roughness.

Hanumanth Gouda et al. [53] found that Hybrid metal matrix composites (MMC's) are significant kind of engineering materials used in automotive, aerospace, marine hardware and other applications because of their lower density, cast ability and better mechanical and wear properties compared to pure aluminum. So, an effort is made to study density, wear and corrosion resistance of A356 alloy based hybrid composites containing RHA and $\mathrm{Al}_{2} \mathrm{O}_{3}$ particulates in equal proportions ( $1 \mathrm{wt} \%, 2 \mathrm{wt} \%, 3 \mathrm{wt} \%, 4 \mathrm{wt} \%$ and $5 \mathrm{wt} \%)$ are studied with different aging conditions. Stir casting is a type of liquid metallurgy technique was employed in which preheated reinforcements were introduced. A scope of enhancement in both corrosion and wear resistance is observed in Double aged with strain specimens over as-cast, single aged and double aged without strain condition. It was also observed that the density of hybrid composites decreased with increasing particle content. The microstructure of the composites was ex- 
amined to analyze the dispersion of $\mathrm{RHA}$ and $\mathrm{Al}_{2} \mathrm{O}_{3}$ particulates in a matrix using optical microscope.

Bahrami A et al. [54] found that there are several advantages in using the agro waste as reinforcements; these cost very less for processing, easily available in massive at an economical price and often lower densities in comparison with some ceramics (such as silicon carbide, boron carbide and alumina), benefit in conservation and protection of the environment.

An overview of the recent studies on AMCs reinforced with agro waste derivatives and synthetic ceramic particulates is presented below. The fabrication characteristics and mechanical behavior of rice husk ash-alumina reinforced Al-Mg-Si alloy matrix hybrid composite produced via stir casting was studied by Alaneme et al. [55], The $10 \mathrm{wt} \%$ reinforcing phase consisted of 2, 3, 4, and $6 \mathrm{wt} \%$ RHA as a complementing reinforcement to alumina. The authors reported that there was a slight decrease in hardness, ultimate tensile strength of the hybrid composites as compared with the single reinforced $\mathrm{Al}-\mathrm{Mg}-\mathrm{Si} / \mathrm{Al}_{2} \mathrm{O}_{3}$ composites. However, composites sample containing $2 \mathrm{wt} \%$ exhibited higher specific strength, percentage elongation and fracture toughness than the single reinforced AMCs. The slight reduction in yield strength, ultimate tensile strength and hardness was attributed to lower hardness value of silica, which is the predominant compound in the rice husk ash.

Prasad et al. [56], carried out an investigation on stir cast aluminium hybrid composite containing equal amount of rice husk ash and silicon carbide from $2 \%$ to $8 \%$ in step of 2 . They found out that there was homogenous distribution of the reinforcement in the matrix. Hardness, yield strength and ultimate tensile strength increased with increase in the reinforcement while percentage elongation and CTE had inverse relationship with increasing reinforcement.

An effort has been made by Poornesh M. et al. [57], that to study about the properties of the composites prepared by reinforcing pure aluminum metal with varying percentage of Coconut Shell Ash and SiC particles. The composites were prepared using stir casting process with bottom pouring at a pre-set melting temperature and stirring speed. The produced composites were then studied for mechanical properties like hardness, density etc. It was noticed from the results, that the inclusion of ash and ceramic particles has a significant influence on the mechanical properties but will make the composites brittle.

Recently research work carried out by Gladstone et al. [58], that the applications of Al-MMCs are limited by high cost and hence the search for cheap agricultural materials as reinforcements to enhance their applications. Rice husk ash $(2-3 \mu \mathrm{m})$ has been used to reinforce AA6061 aluminum alloy and it was reported that the reinforcement distributes uniformly in the matrix and enhanced the tensile strength and hardness with increase in mass fraction of the reinforcement up $8 \%$ over the unreinforced alloy.

Also it was recently reported by several authors, that utilization of agricultural wastes as filler for Al-MMCs [59] [60] and [61]. Agricultural wastes are cheap compared to carbide, oxide and boride fillers. They constitute environmental 
problems, hence, the need to find useful applications for them.

\section{Conclusions}

Based on the extensive literature survey following conclusions can be made as given:

- The mechanical properties like hardness, impact strength, compressive strength, tensile strength were increased with increase in reinforcement percentage.

- Also other properties like physical properties like density decreased when composites reinforced with reinforcements like Agro waste ash as reinforcement.

- The mechanical property like hardness ultimate tensile strength was decreased with hybrid composite compared with single reinforcement.

- The Corrosion properties were reviewed; it is concluded that the corrosion resistance property increases with agro waste ash reinforcement.

- The Wear or tribological properties were reviewed; it is concluded that the wear resistance property increases with increase in content of hybrid reinforcement compared to single reinforcement like agro waste ash.

Finally there is immense potential, scope and opportunities for research in the field of prediction on tribological and mechanical properties of the Aluminum alloys by reinforcing with different agro waste ashes as a reinforcement.

\section{Acknowledgements}

We take it as a privilege to express through this paper a few words of cordial gratitude and respect to all those who guided and inspired us at every step towards the completion of this project. We here acknowledge our sincere and heartfelt gratitude to our respected principal Dr. B Shivkumara, HOD and all staff members and friends for providing a healthy environment in the college, which helped in concentrating on the task.

\section{Conflicts of Interest}

The authors declare no conflicts of interest regarding the publication of this paper.

\section{References}

[1] Panigrahi, S.K. and Jayaganthan, R. (2010) Effect of Annealing on Precipitation, Microstructural Stability, and Mechanical Properties of Cry Rolled Al 6063 Alloy. Journal of Materials Science, 45, 5624-5636. https://doi.org/10.1007/s10853-010-4627-9

[2] Panigrahi, S.K. and Jayaganthan, R. (2009) Development of Ultrafine-Grained Al 6063 Alloy by Cryorolling with the Optimized Initial Heat Treatment Conditions. Materials \& Design, 32, 2172-2180. https://doi.org/10.1016/j.matdes.2010.11.027

[3] Panigrahi, S.K., Jayaganthan, R. and Pancholi, V. (2009) Effect of Plastic Deformation Conditions on Microstructural Characteristics and Mechanical Properties of Al 
6063 Alloy. Materials \& Design, 30, 1894-1901.

[4] Al-Fadhalah, K.J., Almazrouee, A.I. and Aloraier, A.S. (2014) Microstructure and Mechanical Properties of Multi-Pass Friction Stir Processed Aluminum Alloy 6063. Materials \& Design, 53, 550-560.

[5] Allison, J.E. and Cole, G.S. (1993) Metal-Matrix Composites in the Automotive Industry: Opportunities and Challenges. JOM, 45, 19-24. https://doi.org/10.1007/BF03223361

[6] Sirahbizu Yigezu, B., Mahapatra, M.M. and Jha, P.K. (2013) Influence of Reinforcement Type on Microstructure, Hardness, and Tensile Properties of an Aluminum Alloy Metal Matrix Composite. Journal of Minerals and Materials Characterization and Engineering, 1, 124-130. https://doi.org/10.4236/jmmce.2013.14022

[7] Alaneme, K.K. and Aluko, A.O. (2012) Fracture Toughness (K1C) and Tensile Properties of as Cast and Age-Hardened Aluminum (6063)-Silicon Carbide Particulate Composites. Scientia Iranica, 19, 992-996.

[8] Bhandakkar, A., Prasad, R.C. and Sastry, S.M. (2014) Fracture Toughness ofAA2024 Aluminum Fly Ash Metal Matrix Composites. International Journal of Composite Materials, 4, 108-124.

[9] Alaneme, K.K. and Bodunrin, M.O. (2013) Mechanical Behavior of Alumina Reinforced Al6063 Metal Matrix Composites Developed by Two Step-Stir Casting Process. Acta Technica Corvininesis-Bulletin of Engineering, 6, 105-110.

[10] Anilkumar, H.C., Hebbar, H.S. and Ravishankar, K.S. (2011) Mechanical Properties of Fly Ash Reinforced Aluminum Alloy (Al6061) Composites. International Journal of Mechanical and Materials Engineering, 6, 41-45.

[11] Panwar, N. and Chauhan, A. (2014) Development of Aluminum Composites Using Red Mud as Reinforcement-A Review. 2014 Recent Advances in Engineering and Computational Sciences, Chandigarh, India, 6-8 March 2014, 1-4. https://doi.org/10.1109/RAECS.2014.6799610

[12] Abbasipour, B., Niroumand, B. and Vaghefi, S.M. (2010) Compo Casting of A356-CNT Composite. Transactions of Nonferrous Metals Society of China, 20, 1561-1566. https://doi.org/10.1016/S1003-6326(09)60339-3

[13] Erturun, V. and Karamis, M.B. (2016) Effects of Reciprocating Extrusion Process on Mechanical Properties of AA 6061/SiC Composites. Transactions of Nonferrous Metals Society of China, 26, 328-338. https://doi.org/10.1016/S1003-6326(16)64123-7

[14] Hu, C., Yan, H.-G., Chen, J.-H. and Su, B. (2016) Microstructures and Mechanical Properties of 2024Al/Gr/SiC Hybrid Composites Fabricated by Vacuum Hot Pressing. Transactions of Nonferrous Metals Society of China, 26, 1259-1268. https://doi.org/10.1016/S1003-6326(16)64226-7

[15] Vasantha Kumar, C.A. and Rajadurai, J.S. (2016) Influence of Rutile $\left(\mathrm{TiO}_{2}\right)$ Content on Wear and Micro Hardness Characteristics of Aluminum-Based Hybrid Composites Synthesized by Powder Metallurgy. Transactions of Nonferrous Metals Society of China, 26, 63-73. https://doi.org/10.1016/S1003-6326(16)64089-X

[16] Devaraju, A., Kumar, A. and Kotiveerachari, B. (2013) Influence of Addition of $\mathrm{Gr}_{\mathrm{p}} / \mathrm{Al}_{2} \mathrm{O}_{3 \mathrm{p}}$ with $\mathrm{SiC}_{\mathrm{p}}$ on Wear Properties of Aluminum Alloy 6061-T6 Hybrid Composites via Friction Stir Processing. Transactions of Nonferrous Metals Society of China, 23, 1275-1280. https://doi.org/10.1016/S1003-6326(13)62593-5

[17] Lijay, K.J., Selvam, J.D.R., Dinaharan, I. and Vijay, S.J. (2016) Microstructure and Mechanical Properties Characterization of AA6061/TiC Aluminum Matrix Composites Synthesized by in Situ Reaction of Silicon Carbide and Potassium Fluotitanate. 
Transactions of Nonferrous Metals Society of China, 26, 1791-1800. https://doi.org/10.1016/S1003-6326(16)64255-3

[18] Ashok Kumar, B. and Murugan, N. (2012) Metallurgical and Mechanical Characterization of Stir Cast AA6061-T6-AlN $\mathrm{p}_{\mathrm{p}}$ Composite. Materials and Design, 40, 52-58. https://doi.org/10.1016/j.matdes.2012.03.038

[19] Tan, X.-F., Zeng, F.-H., Wang, S.-Q., Zhou, F. and Xiong, X. (2014) Effects of Heat Treatment on Phase Contents and Mechanical Properties of Infiltrated $\mathrm{B}_{4} \mathrm{C} / 2024 \mathrm{Al}$ Composites. Transactions of Nonferrous Metals Society of China, 24, 2359-2365. https://doi.org/10.1016/S1003-6326(14)63357-4

[20] Jiang, X.-S., Wang, N.-J. and Zhu, D.-G. (2014) Friction and Wear Properties of in Situ Synthesized $\mathrm{Al}_{2} \mathrm{O}_{3}$ Reinforced Aluminum Composites. Transactions of Nonferrous Metals Society of China, 24, 2352-2358. https://doi.org/10.1016/S1003-6326(14)63356-2

[21] Zhong, L.-H., Zhao, Y.-T., Zhang, S.-L., Chen, G., Hen, S. and Liu, Y.-H. (2013) Microstructure and Mechanical Properties of in Situ $\mathrm{TiB}_{2} / 7055$ Composites Synthesized by Direct Magneto Chemistry Melt Reaction. Transactions of Nonferrous Metals Society of China, 23, 2502-2508. https://doi.org/10.1016/S1003-6326(13)62761-2

[22] Alidokht, S.A., Abdollah-Zadeh, A., Soleymani, S. and Assadi, H. (2011) Microstructure and Tribological Performance of an Aluminium Alloy Based Hybrid Composite Produced by Friction Stir Processing. Materials and Design, 32, 2727-2733. https://doi.org/10.1016/j.matdes.2011.01.021

[23] Pugacheva, N.B., Michurov, N.S. and Bykova, T.M. (2016) Structure and Properties of the Al/SiC Composite Material. The Physics of Metals and Metallographic, 117, 634-640. https://doi.org/10.1134/S0031918X16060119

[24] Mahdavi, S. and Akhlaghi, F. (2011) Effect of the Graphite Content on the Tribological Behavior of $\mathrm{Al} / \mathrm{Gr}$ and $\mathrm{Al} / 30 \mathrm{SiC} / \mathrm{Gr}$ Composites Processed by in Situ Powder Metallurgy (IPM) Method. Tribology Letters, 44, 1-12. https://doi.org/10.1007/s11249-011-9818-2

[25] Marin, E., Lekka, M., Andreatta, F., Fedrizzi, L., Itskos, G., Moutsatsou, A., Koukouzas, N. and Kouloumbi, N. (2012) Electrochemical Study of Aluminum-Fly Ash Composites Obtained by Powder Metallurgy. Materials Characterization, 69, 16-30. https://doi.org/10.1016/j.matchar.2012.04.004

[26] Prakash, K.S., Kanagaraj, A. and Gopal, P.M. (2015) Dry Sliding Wear Characterization of Al 6061/Rock Dust Composite. Transactions of Nonferrous Metals Society of China, 25, 3893-3903. https://doi.org/10.1016/S1003-6326(15)64036-5

[27] Aigbodion, V.S., Hassan, S.B., Dauda, E.T. and Mohammed, R.A. (2011) Experimental Study of Ageing Behaviour of Al-Cu-Mg/Bagasse Ash Particulate Composites. Tribology in Industry, 33, 28-35.

[28] Allwyn Kingsly, G.J., Mohamed, S.N., Dinaharan, I.J. and David, R.S.J. (2015) Production and Characterization of Rich Husk Ash Particulate Reinforced AA6061 Aluminum Alloy Composites by Compo Casting. Transactions of Nonferrous Metals Society of China, 25, 683-691. https://doi.org/10.1016/S1003-6326(15)63653-6

[29] Ankesh, K., Kanhaiya, K., Suman, S. and Siva, S.R.R. (2016) Study of Physical, Mechanical and Machinability Properties of Aluminium Metal Matrix Composite Reinforced with Coconut Shell Ash Particulates. Imperial Journal of Interdisciplinary Research, 2, 151-157.

[30] Oladele, I.O. and Okoro, A.M. (2016) The Effect of Palm Kernel Shell Ash on the Mechanical Properties of as-Cast Aluminium Alloy Matrix Composites. Leonardo 
Journal of Sciences, 15, 15-30.

[31] Alaneme, K.K., Eze, H.I. and Bodunrin, M.O. (2015) Corrosion Behavior of Groundnut Shell Ash and Silicon Carbide Hybrid Reinforced Al-Mg-Si Alloy Matrix Composites in $3.5 \% \mathrm{NaCl}$ and $0.3 \mathrm{M} \mathrm{H}_{2} \mathrm{SO}_{4}$ Solutions. Leonardo Electronic Journal of Practices and Technologies, 14, 129-146.

[32] Cociña, E.V., Morales, E.V., Santos, S.F., Savastano Jr., H. and Frías, M. (2011) Behavior of Bamboo Leaf Ash: Characterization and Determination of the Kinetic $\mathrm{Pa}$ rameters. Cement \& Concrete Composites, 33, 68-73. https://doi.org/10.1016/j.cemconcomp.2010.09.003

[33] Atuanya, C.U., Ibhadode, A.O.A. and Dagwa, I.M. (2012) Effects of Breadfruit Seed Hull Ash on the Microstructures and Properties of Al-Si-Fe Alloy/Breadfruit Seed Hull Ash Particulate Composites. Results in Physics, 2, 142-149.

https://doi.org/10.1016/j.rinp.2012.09.003

[34] Kumar, A. (2016) Study of Physical, Mechanical and Machinability Properties of Aluminum Metal Matrix Composite Reinforced with Coconut Shell Ash particulates. Imperial Journal of Interdisciplinary Research, 2, 2454-1362.

[35] Hassan, S.B. (2015) Effects of Eggshell on the Microstructures and Properties of Al-Cu-Mg/Eggshell Particulate Composite. Journal of King Saud University-Engineering Sciences, 27, 49-56. https://doi.org/10.1016/j.jksues.2013.03.001

[36] Saravanan, S.D. (2013) Effect of Particle Size on Tribological Behavior of Rice Husk Ash-Reinforced Aluminum Alloy ( $\mathrm{AlSi}_{10} \mathrm{Mg}$ ) Matrix Composites. Tribology Transactions, 56, 1156-1167. https://doi.org/10.1080/10402004.2013.831962

[37] Asafa, T.B. (2015) Potentials of Snailshell as Reinforcement for Discarded Aluminum Based Materials. International Journal of Advanced Science and Technology, 84, 1-8.

[38] Omole, S.O., Akinfolarin, J.F. and Oluyori, R.T. (2014) Assessment of Hardness and Tensile Properties of Stir-Cast Aluminum Matrix Reinforced With Tetracarpidium Conophorum Kernel. International Journal of Engineering and Applied Sciences, 4 , 19-22.

[39] Fatile, O.B., Akinruli1, J.I. and Amori, A.A. (2014) Microstructure and Mechanical Behaviour of Stir-Cast Al-Mg-Sl Alloy Matrix Hybrid Composite Reinforced with Corn Cob Ash and Silicon Carbide. International Journal of Engineering and Technology Innovation, 4, 251-259.

[40] Alaneme, K. and Adewuyi, E. (2013) Mechanical Behavior of Al-Mg-Si Matrix Composites Reinforced with Alumina and Bamboo Leaf Ash. Metallurgical \& Materials Engineering, 177-187.

[41] Ajibola, P.W.A., Amori, PA.A. and Dada, P.A. (2015) Microstructural and Mechanical Characterization of Reinforced Aluminum Composite (MMC). International Journal of Scientific Engineering and Applied Science, 1, 86-97.

[42] Atuanya, C., Onukwuli, O. and Aigbodion, V. (2014) Experimental Correlation of Wear Parameters in Al-Si-Fe Alloy/Breadfruit Seed Hull Ash Particulate Composites. Journal of Composite Materials, 48, 1487-1496.

https://doi.org/10.1177/0021998313487935

[43] Prasad, D.S., Shoba, C. and Ramanaiah, N. (2014) Investigations on Mechanical Properties of Aluminum Hybrid Composites. Journal of Materials Research and Technology, 3, 79-85. https://doi.org/10.1016/j.jmrt.2013.11.002

[44] Alaneme, K.K., Ademilua, B.O. and Bodunrin, M.O. (2013) Mechanical Properties and Corrosion Behavior of Aluminum Hybrid Composites Reinforced with Silicon 
Carbide and Bamboo Leaf Ash. TribolInd, 35, 25-35.

[45] Ahamed, A.A., Ahmed, R., Hossain, M.B. and Billah, M. (2016) Fabrication and Characterization of Aluminium-Rice Husk Ash Composite Prepared by Stir Casting Method. Journal of Science \& Engineering, 44, 9-18.

https://doi.org/10.3329/rujse.v44i0.30361

[46] Praveen Kumar, B. and Birru, A.K. (2017) Microstructure and Mechanical Properties of Aluminum Metal Matrix Composites with Addition of Bamboo Leaf Ash by Stir Casting Method. Rajshahi University Journal of Science and Engineering, 44, 9-18. https://doi.org/10.1016/S1003-6326(17)60284-X

[47] Madakson, P., Yawas, D. and Apasi, A. (2012) Characterization of Coconut Shell Ash for Potential Utilization in Metal Matrix Composites for Automotive Applications. International Journal of Engineering Science and Technology, 4, 1190-1198.

[48] Aigbodion, V.S. (2012) Development of Al-Si-Fe/Rice Husk Ash Particulate Composites Synthesis by Double Stir Casting Method. Usak University Journal of Material Sciences, 2, 187-197.

[49] Deshmukh, P. and Pathak, S. (2012) Influence of Varying $\mathrm{SiO}_{2} \%$ on the Mechanical Properties of Al Based MMC. Transactions of the Indian Institute of Metals, 65, 741-745. https://doi.org/10.1007/s12666-012-0196-8

[50] Lancaster, L., Lung, M.H. and Sujan, D. (2013) Utilization of Agro-Industrial Waste in Metal Matrix Composites: Towards Sustainability. International Journal of Environmental, Chemical, Ecological, Geological and Geophysical Engineering, 7, 25-33.

[51] Senapati, A.K. (2015) A Review on Utilization of Waste Material as Reinforcement in MMCs. International Journal of Research in Advent Technology, 3.

[52] Kumar, A., Kumar, K., Saurav, S. and Sankar Raju, S. (2016) Study of Physical, Mechanical and Machinability Properties of Aluminium Metal Matrix Composite Reinforced with Coconut Shell Ash Particulates. Imperial Journal of Interdisciplinary Research, 2, 151-157.

[53] Gowdaa, H. and Rajendra Prasad, P. (2016) Evaluation of Wear and Corrosion Resistance of A356 Alloy Based Hybrid Composite at Different Aging Conditions. International Journal of Materials Science, 11, 57-69.

[54] Bahrami, A., Soltani, N., Pech-Canul, M.I. and Gutierrez, C.A. (2015) Development of Metal-Matrix Composites from Industrial/Agricultural Waste Materials and Their Derivatives. Critical Reviews in Environmental Science and Technology, 46, 143-208. https://doi.org/10.1080/10643389.2015.1077067

[55] Alaneme, K.K., Akintunde, I.B., Olubambi, P.A. and Adewale, T.M. (2013) Fabrication Characteristics and Mechanical Behavior of Rice Husk Ash-Alumina Reinforced Al-Mg-Si Alloy Matrix Hybrid Composites. Journal of Materials Research and Technology, 2, 60-67. https://doi.org/10.1016/j.jmrt.2013.03.012

[56] Prasad, S.D. and Krishna, R.A. (2011) Production and Mechanical Properties of A356.2 RHA Composite. International Journal of Advance Science and Technology, 33, 51-58.

[57] Poornesh, M., Saldanha, J.X., Singh, J. and Gavin Manuel Pinto, G. (2017) Effect of Coconut Shell Ash and SiC Particles on Mechanical Properties of Aluminium Based Composites. American Journal of Materials Science, 7, 112-115.

[58] Gladston, J.A., Sheriff, N.M., Dinaharan, I. and Selvam, J.D. (2015) Production and Characterization of Rich Husk Ash Particulate Reinforced AA6061 Aluminum Alloy Composites by Compocasting. Transaction of the Nonferrous Society of China, 25, 683-691. https://doi.org/10.1016/S1003-6326(15)63653-6 
[59] Agunsoye, J., Talabi, S., Bello, S. and Awe, I. (2014) The Effects of Cocos Nucifera (Coconut Shell) on the Mechanical and Tribological Properties of Recycled Waste Aluminium Can Composites. Tribology in Industry, 36, 155-162.

[60] Usman, A., Raji, A., Hassan, M. and Waziri, N. (2014) A Comparative Study on the Properties of Al-7\%Si-Rice Husk Ash and Al-7\%Si-Bagasse Ash Composites Produced by Stir Casting. The International Journal of Engineering and Science, 3, 1-7.

[61] Saravanan, S. and Senthilkumar, M. (2014) Mechanical Behavior of Aluminum (Al$\mathrm{Si}_{10} \mathrm{Mg}$ )-RHA Composite. International Journal of Engineering and Technology, 5, 4834-4840. 